\title{
OLD WORLD GESNERIACEAE X: BORNEAN SPECIES OF CYRTANDRA ALLIED TO C. PHOENICOLASIA
}

\author{
O. M. Hilliard \& B. L. BurtT
}

Cyrtandra phoenicolasia, C. hottae and five new species constitute a group distinguished by a suite of characters including setose vegetative parts, deeply divided calyx, small white corolla marked on the lower lip with yellow to brown, unilateral disc, ovary constricted at base, and fruit small. All species are fully described and an identification key provided.

Keywords. Borneo, Cyrtandra, Gesneriaceae, new species.

\section{INTRODUCTION}

The group of species closely allied to Cyrtandra phoenicolasia Lauterb. and C. hottae B.L.Burtt share the following characteristics: stem simple above the base, leafy towards the apex (lower leaves shed), often floriferous well below the leaves, conspicuous brown bristles (setae) on all vegetative parts, inflorescence an axillary tightly congested, dichasial cyme, peduncle not exceeding c.35mm, mostly much shorter (3-10mm), calyx deeply divided (roughly halfway in C. phoenicolasia, otherwise nearly to the base), corolla small (c.12-20mm), white marked with yellow to brown on the lower lip, ovary glabrous, constricted at base on ventral side to accommodate the fleshy unilateral disc, style puberulous or minutely gland-dotted, fruit small (c.5-15mm long), pericarp verrucose.

In the shortly pedunculate, very congested inflorescence, deeply divided calyx, small white corolla, ovary constricted at the base to accommodate the unilateral disc, and in their small fruits, C. phoenicolasia and its allies resemble C. chrysea and its allies (Hilliard \& Burtt, 2004). The latter group, although variously hairy, differs in its lack of brown bristles and also in the pink to purple (not yellow to brown) markings on the corolla.

\section{Key to species}

1a. Leaves with two conspicuous balloon-like pouches c.7-8mm in diam. at each node formed by the united bases of the petiolar wings 1. C. phoenicolasia

1b. Leaves without such pouches 2 
2a. Hairs on stems closely appressed; largest major leaves c. $37-45 \mathrm{~mm}$ broad, minor leaf roughly one-tenth to one-third length of major leaf 7. C. hottae

2b. Hairs on stems spreading; largest major leaves $50-150 \mathrm{~mm}$ broad; if leaves anisophyllous, then minor leaf one-third to two-thirds length of major leaf _ 3

3a. Peduncles $15-35 \mathrm{~mm}$ long 2. C. megaphylla

3b. Peduncles c. $3-7 \mathrm{~mm}$ long 4

4a. Bristles on stem 1.5-2mm long 6. C. brevisetosa

4b. Bristles on stem $5-8 \mathrm{~mm}$ long 5

5a. Outermost bracts $20-30 \times 5-11 \mathrm{~mm}$, both midrib and lateral veins clearly visible on lower surface, calyx lobes $3-5 \mathrm{~mm}$ long 4. C. latibracteata

5b. Outermost bracts c. $12-20 \times 1.5-3 \mathrm{~mm}$, veins invisible, calyx lobes c. $2-3 \mathrm{~mm}$ long

6a. Bracts $12-16 \times 2-3 \mathrm{~mm}$, lanceolate, acuminate 3. C. phoenicoides

6b. Bracts $15-20 \times 1.5-2 \mathrm{~mm}$ at base, rapidly and abruptly narrowing to less than $1 \mathrm{~mm}$

5. C. dorytricha

1. Cyrtandra phoenicolasia Lauterb., Bot. Jahrb. 44: 541 (1910).

Lectotype (chosen here): Borneo, Kalimantan, zwischen Semurung und Sungai Tarik $\left[10^{\circ} 50^{\prime} \mathrm{S}, 115^{\circ} 50^{\prime} \mathrm{E}\right]$, Urwald, Bachrand, 18 vii 1908, Winkler 3026 (lecto. WRSL; photocopy E; isolecto. BM, K, L).

Herb, stem to c.600mm long, 4-5mm diam., simple, decumbent at base and rooting there, thickly clad in brown bristles c. $3-5 \mathrm{~mm}$ long. Leaves opposite, anisophyllous, minor leaf roughly a third as long to half as long as major leaf, largest major leaves 120-200 $\times 55-85 \mathrm{~mm}$, obovate, apex abruptly acute, base cuneate, decurrent, margins serrate to serrulate, each tooth a vein-ending, lateral veins 10-12 each side of midrib, tertiary veins coarsely reticulate, all veins strongly raised on lower surface, upper surface clad in scattered brown bristles $3-5 \mathrm{~mm}$ long, c. $2 \mathrm{~mm}$ on margins, a small 'shield' (outgrowth of blade) c.6-7.5 $\times 5-7.5 \mathrm{~mm}$ at base of midrib, apical half free of midrib, lower surface glabrous between the veins, all veins and veinlets densely appressed-pubescent, bristly as well, bristles to $3-4 \mathrm{~mm}$ long; petiole c.10-15mm long, winged by decurrent blade, wings broadening at base and united with wings of opposing leaf to form a deep pouch c.7-8 $\times 7-8 \mathrm{~mm}$. Inflorescence a dichasial cyme, solitary in leaf axils, flowers c.10, tightly clustered; peduncle c. $8-10 \mathrm{~mm}$, densely bristly. Bracts c. $13-17 \times 2-8 \mathrm{~mm}$, sublinear to elliptic, acuminate, venation clearly visible particularly on lower surface, brown bristles to c. $4 \mathrm{~mm}$ on margins, fewer on inner and outer surfaces, bracteoles similar but narrower. Pedicels 2-4mm long, bristly. Calyx 2-3mm long, campanulate, tube 1-2mm, lobes 5, $1-1.5 \times 0.8-1 \mathrm{~mm}$, bristly to glabrous. Corolla white with 2 raised yellow keels on lower lip running down into throat, c.14-17mm long, tube 9.5-12mm, cylindric at base, then abruptly expanded and ventricose on lower side, bilabiate, lower lip 4.5-5 × 7-9mm, median lobe $2.2-2.5 \times 4 \mathrm{~mm}$, upper lip $3-4 \times 4.4-5 \mathrm{~mm}$, notched, 
outside with plentiful hairs to c. $1.5 \mathrm{~mm}$ long, inside very minutely hairy on keels and sometimes on upper lip and median lobe of lower lip. Stamens inserted c.5-7mm above base of tube, filaments $4-5 \mathrm{~mm}$ long, slightly swollen near apex and there very minutely hairy, eventually twisted once near base, anthers $1-1.2 \times 0.8-1.1 \mathrm{~mm}$, cohering apically by a very small apiculus; lateral staminodes $1-1.3 \mathrm{~mm}$, posticous staminode wanting. Disc $1.2-1.5 \times 0.7-0.8 \mathrm{~mm}$, unilateral. Ovary c. $3.5 \mathrm{~mm}$, glabrous (not shortly pilose as originally described), constricted at base to accommodate disc. Style 4.5-5.5mm, appressed-pubescent. Stigmatic lobes c. $0.8 \times 0.5 \mathrm{~mm}$. Fruit $6-7 \times$ 3-3.5mm, pericarp verrucose. Seeds c. $0.3 \times 0.2 \mathrm{~mm}$, testa red-brown.

Other specimens examined. Kalimantan. Zwischen Batu babi und Lumowia [c. $1^{\circ} 45^{\prime} \mathrm{S}$, $115^{\circ} 45^{\prime} \mathrm{E}$ ], 10 vii 1908, Winkler 2860 (syntype WRSL, BM; photo. E). Around Jelini, along Sungai Belayan, NW of Tabang [ $\left.0^{\circ} 34^{\prime} \mathrm{N}, 116^{\circ} 02^{\prime} \mathrm{E}\right], 100-150 \mathrm{~m}, 12$ i 1979, Murata et al. B1185 (L), B-1172 (L). W. Koetai, no. 36, near Long Petah, 450m, 16 ix 1925, Endert 3378 (L).

SARAWAK. Ulu Sungai Sedampa, extreme headwaters of Batang Balleh, $1^{\circ} 34^{\prime} \mathrm{N}, 114^{\circ} 30^{\prime} \mathrm{E}$, 1500ft, 2 vii 1969, Anderson \& Paie S28354 (E). Nanga Balang, extreme headwaters of Batang Balleh, $1^{\circ} 35^{\prime} \mathrm{N}, 114^{\circ} 30^{\prime} \mathrm{E}, 950 \mathrm{ft}, 29$ vi 1970, Anderson S28312 (E, L). Balang/Balleh watershed ridge, extreme headwaters of Balleh river, foothills of Bukit Batu Tibang, $1^{\circ} 35^{\prime} \mathrm{N}, 114^{\circ} 33^{\prime} \mathrm{E}$, 2800ft, 6 vii 1969, Anderson S28460 (E, L).

A remarkable feature of $C$. phoenicolasia is the two deep pouches at each node formed by the union of the winged bases of the petioles of each pair of leaves. In addition, there is a shield-shaped structure on the upper surface of the leaf astride the midrib near its base. This appears to be an outgrowth of the blade, attached to the midrib only in its lower half. What purpose it serves is unknown; the pouches are possibly 'compost pits', though in one specimen seen (Anderson S28640) they were filled with small seeds, perhaps cached there by ants. Union of winged petioles to form 'pockets' has been recorded in several other, unrelated, species of Cyrtandra, but, so far as is known, never in the form recorded here.

Specimens from Kalimantan appear to have bracts broader than in those from Sarawak, but this needs confirmation on more plentiful material.

A broad concept of $C$. phoenicolasia has hitherto included a number of allied species newly described below as $C$. brevisetosa, $C$. dorytricha, C. latibracteata, $C$. megaphylla and $C$. phoenicoides. All lack the leaf pouches of $C$. phoenicolasia and differ further in several respects, including a more deeply divided calyx.

Plants of $C$. phoenicolasia favour outcrops, boulders and cliffs in forest along streams, from SE Sarawak eastwards across Kalimantan, between 300 and $850 \mathrm{~m}$ above sea level.

The leaves lack a hypodermis and there are no sclereids in the mesophyll.

2. Cyrtandra megaphylla Hilliard \& B.L.Burtt, sp. nov. a C. phoenicolasia Lauterb. foliis multo majoribus (c. $270-370 \times 88-150 \mathrm{~mm}$ nec $120-200 \times 55-85 \mathrm{~mm})$, petiolis alatis haud saccum altum ad nodos formantibus (nec petiolis alatis saccum altum formantibus), venis lateralibus foliorum maximorum 13-20 (nec 10-12), pedunculis 15-35mm longis (nec $8-10 \mathrm{~mm}$ ), calyce fere ad basim lobato (nec plus minusve ad medium) distinguenda. 
Type: Borneo, Sarawak, Sungai Bena, tributary of Sungai Sut, c. $1^{\circ} 55^{\prime} \mathrm{N}, 113^{\circ} 5^{\prime} \mathrm{E}$, 23 vii 1962, Burtt B2603 (holo. E).

Herb, stem to $1 \mathrm{~m}$ tall, probably decumbent at base (adventitious roots present), c.7$10 \mathrm{~mm}$ diam., thickly clad in brown bristles $7-12 \mathrm{~mm}$ long, leafy only towards apex. Leaves opposite, anisophyllous, minor leaf roughly one-half to two-thirds as long as major leaf, largest major leaves $270-370 \times 88-150 \mathrm{~mm}$, including petiolar part, obovate, apex rather abruptly acute, base cuneate, decurrent down very short petiole in wings c. $8-10 \mathrm{~mm}$ broad, wings of leaf pairs briefly united at base, margins serrulate, each tooth a vein-ending, lateral veins 13-20 each side of midrib, tertiary veins coarsely reticulate, often scalariform towards margins and apex, upper surface clad in scattered bristles 3-4mm long, lower surface glabrous between the veins, all veins and veinlets densely appressed-pubescent, spreading brown bristles $8-10 \mathrm{~mm}$ long as well, longest on midrib. Inflorescence a many-flowered very congested, axillary, dichasial cyme; peduncles $15-34 \mathrm{~mm}$ long, clad in brown bristles c. $4 \mathrm{~mm}$ long. Bracts c. $18-30 \times 3-5 \mathrm{~mm}$, lanceolate, acuminate, venation obscure, brown bristles to c. $5 \mathrm{~mm}$ long on both surfaces, bracteoles similar but narrower and slightly shorter. Pedicels c. $2-5 \mathrm{~mm}$ long, bristly. Calyx 5-lobed nearly to base, tube c. $0.25-0.5 \mathrm{~mm}$ long, lobes $2-2.5 \times 0.8-1.2 \mathrm{~mm}$, narrowly triangular, bristles $1-2 \mathrm{~mm}$ long outside. Corolla white with 2 yellow bars on palate darkening to brown in throat, c.19mm long, tube $13 \mathrm{~mm}$, cylindric at base, then abruptly expanded and ventricose on lower side, bilabiate, lower lip c. $6 \times 11 \mathrm{~mm}$, median lobe $3 \times 4.5-5.5 \mathrm{~mm}$, upper lip $3 \times 7-8 \mathrm{~mm}$, lobes $3 \times 4 \mathrm{~mm}$, outside brown appressed hairs to $1 \mathrm{~mm}$ long, inside minute hairs on lower lip, particularly on the yellow bars. Stamens inserted $8 \mathrm{~mm}$ above base of tube, filaments $5.5 \mathrm{~mm}$ long, twisted once, anthers $1.5 \times 1.25 \mathrm{~mm}$, cohering face to face by a very small apiculus; lateral staminodes $1 \mathrm{~mm}$ long, posticous staminode $0.5 \mathrm{~mm}$. Disc $1.2 \times 2 \mathrm{~mm}$, unilateral. Ovary $6.5 \times 1.25 \mathrm{~mm}$, constricted at base to accommodate the disc, glabrous. Style $6 \mathrm{~mm}$, very minutely gland-dotted. Stigmatic lobes c. $1 \times 0.8 \mathrm{~mm}$. Fruit $8-15 \times 3-4.5 \mathrm{~mm}$, pericarp verrucose. Seeds c. $0.3 \times 0.2 \mathrm{~mm}$, testa red-brown.

Other specimens examined. SARAwAK. Batu Laga Plateau, Ulu Sungai Kebhor, Batang Balui [c. $2^{\circ} 42^{\prime} \mathrm{N}, 113^{\circ} 47^{\prime} \mathrm{E}$ ], 600m, 6 iii 1989, Yii S56515 (K). Sungai Bena area, $1^{\circ} 56^{\prime} \mathrm{N}, 113^{\circ} 8^{\prime} \mathrm{E}$, 23 iv 1980, Burtt B12945 (E). Sungai Merating, Bena Sut, Kapit, 23 iv 1980, Paie S41000 (E, L). Sungai Kerangan Limo, Mengiong, Kapit, [c. $1^{\circ} 30^{\prime}$ N, $113^{\circ} 30^{\prime} \mathrm{E}$ ], 500m, 9 xi 1979, Othman et al. S41331 (E, L).

Cyrtandra megaphylla (megaphylla = large leaves), like the rest of the species in this group, differs sharply from $C$. phoenicolasia by the lack of pouches at the nodes derived from the united petiolar wings of the leaf-pairs and in having the calyx divided nearly to the base (not roughly halfway). It differs from all other species included here in its much longer peduncles, $15-35 \mathrm{~mm}$ versus $3-10 \mathrm{~mm}$.

The distribution of $C$. megaphylla as currently known is confined to Sarawak between $1^{\circ} 30^{\prime}$ and $2^{\circ} 42^{\prime} \mathrm{N}$ and $113^{\circ} 5^{\prime} \mathrm{S}$ to $47^{\prime} \mathrm{E}$, while that of $C$. phoenicolasia is further south and east, between $1^{\circ} 35^{\prime} \mathrm{N}$ to $1^{\circ} 50^{\prime} \mathrm{S}, 114^{\circ} 30^{\prime} \mathrm{E}$ to $116^{\circ} 2^{\prime} \mathrm{E}$, from 
E Sarawak east across Kalimantan. Cyrtandra megaphylla is a plant of the forest floor along rocky streambanks and on hill slopes, c.500-700m above sea level.

Burtt recorded 'young foliage copper-purple underneath, gradually fading'; Yii 'stems and petioles purplish'. Others commented on the brown or blackish hairs on mature stems and leaves, a feature of this group (they also occur in other groups). The leaves have a one-layered hypodermis and small astrosclereids in the spongy mesophyll.

3. Cyrtandra phoenicoides Hilliard \& B.L.Burtt, sp. nov. a C. megaphylla Hilliard \& B.L.Burtt foliis majoribus cujusque paris c.150-250mm longis (nec 270-370mm), setis in caulibus et in pagina foliorum inferiore ad $5 \mathrm{~mm}$ longis (nec 7-12 mm), pedunculis 3-5mm longis (nec $15-35 \mathrm{~mm}$ ) distinguenda.

Type: Borneo, Sarawak, Gunong Mulu National Park [c. $\left.4^{\circ} 01^{\prime} \mathrm{N}, 114^{\circ} 52^{\prime} \mathrm{E}\right]$, between Sungai Melinau and Sungai Trekan, c.400ft, 15 vi 1975, Burtt B8282 (holo. E).

Herb, stem c.250-500mm long, 4-5mm diam., decumbent and rooting at base, sometimes with a minor branch near base, thickly clad in brown bristles to $5 \mathrm{~mm}$ long. Leaves opposite, more or less isophyllous to anisophyllous and then minor leaf roughly half length of major leaf, largest major leaves $150-250 \times 55-100 \mathrm{~mm}$ long including petiolar part, elliptic to obovate-elliptic, apex acute, base cuneate, decurrent down short petiole in wings c.3-4mm broad, wings of leaf-pairs briefly united at base, margins serrate, lateral veins 11-14 each side of midrib, tertiary veins coarsely reticulate tending to scalariform towards margins, upper surface with scattered brown bristles $2.5-5.5 \mathrm{~mm}$ long, lower surface glabrous between the veins, all veins and veinlets densely appressed-pubescent, brown bristles $4-5.5 \mathrm{~mm}$ as well mainly on midrib and lateral veins. Inflorescence a very congested axillary, dichasial cyme, flowers 10 to many; peduncles $3-5 \mathrm{~mm}$ long, bristly. Bracts $12-16 \times 2-3 \mathrm{~mm}$, lanceolate, acuminate, venation invisible, brown bristles to $3 \mathrm{~mm}$ long mainly on backs and margins, bracteoles similar but narrower. Pedicels $2-7 \mathrm{~mm}$ long, bristly. Calyx 5-lobed nearly to base, tube c. $0.3 \mathrm{~mm}$, lobes $2.25-2.5 \times 0.8 \mathrm{~mm}$, narrowly triangular, few small bristles outside. Corolla white with 2 yellow bars on palate turning brownish in throat, c. $15 \mathrm{~mm}$ long, tube $10 \mathrm{~mm}$, cylindric at base then abruptly expanded and ventricose on lower side, bilabiate, lower lip $5 \times 10 \mathrm{~mm}$, median lobe $2.5 \times 4 \mathrm{~mm}$, upper lip $2 \times 4 \mathrm{~mm}$, notched, outside brown bristles $1.5 \mathrm{~mm}$ long, inside minutely glandular below sinus of upper lip. Stamens inserted c.6mm above base of tube, filaments $4 \mathrm{~mm}$, twisted once, anthers $1 \times 1 \mathrm{~mm}$, cohering face to face by a very small apiculus; staminodes not seen. Disc $1 \times 1 \mathrm{~mm}$, unilateral. Ovary $3 \times 0.8 \mathrm{~mm}$, constricted at base to accommodate disc, glabrous. Style $4 \mathrm{~mm}$, very minutely glanddotted. Stigmatic lobes $0.6 \times 0.4 \mathrm{~mm}$. Fruit $5-6 \times 3-3.5 \mathrm{~mm}$, pericarp verrucose. Seeds c. $0.25 \times 0.2 \mathrm{~mm}$.

Other specimens examined. SARAwaK. Mulu National Park, Bukit Binaret, 28 iv 1985, Abg. Motar et al. S49469 (E). 


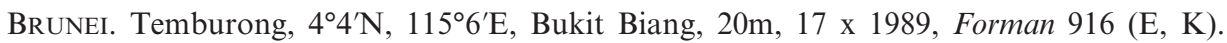
Temburong, $4^{\circ} 32^{\prime} \mathrm{N}, 115^{\circ} 11^{\prime} \mathrm{E}$, Amo, Temburong river, Sungai Bakit N side of Temburong, 45m, 16 vii 1993, S. Atkins 489 (E, K). Temburong, $4^{\circ} 30^{\prime} \mathrm{N}, 115^{\circ} 11^{\prime} \mathrm{E}$, Amo, Bukit Belalong, 500m, 26 ii 1992, Dransfield JD7231 (E). Temburong, $4^{\circ} 30^{\prime} \mathrm{N}, 115^{\circ} 10^{\prime} \mathrm{E}$, E of Kuala Belalong Field Studies Centre, c.70m, 21 ii 1992, Argent \& Mitchell 9182 (E).

Cyrtandra phoenicoides is in the general affinity of $C$. phoenicolasia; the epithet draws attention to this. Its closest ally appears to be $C$. megaphylla, from which it is distinguished by its smaller major leaves (c.150-250mm versus 270-370mm long), shorter bristles on stem and undersurfaces of leaves (up to $5 \mathrm{~mm}$ versus $7-12 \mathrm{~mm}$ ) and shorter peduncles (c.3-5mm versus $15-35 \mathrm{~mm}$ ). Also the bracts are shorter and narrower, and the flowers are possibly smaller, but too few corollas have been seen to be certain.

The two species are well separated geographically, C. megaphylla apparently confined to Sarawak south of $3^{\circ} \mathrm{N}$ latitude, while $C$. phoenicoides is currently known from Brunei and just across the border in Mulu National Park, c. $4-5^{\circ} \mathrm{N}$ latitude.

Cyrtandra phoenicoides occurs between 20 and 500m above sea level, on banks and along streams in the forest. The leaves have small astrosclereids in the spongy mesophyll; a one-layered hypodermis may be present or absent.

4. Cyrtandra latibracteata Hilliard \& B.L.Burtt, sp. nov. a $C$. dorytricha Hilliard \& B.L.Burtt bracteis extimis $20-30 \times 5-11 \mathrm{~mm}$ et costa et venis lateralibus clare visibilibus (nec $15-20 \times 1.5-2 \mathrm{~mm}$ venatione invisibili) calycis lobis $3-5 \mathrm{~mm}$ (nec 2-3mm) longis differt.

Type: Borneo, Sabah, Mt. Kinabalu, eastern shoulder, $6^{\circ} 5^{\prime} \mathrm{N}, 116^{\circ} 36^{\prime}-40^{\prime} \mathrm{E}, 3500 \mathrm{ft}$, 18 vi 1961, Chew et al. 643 (holo. E; iso. K, L).

Herb, stem c.300-650mm long, 6-8mm diam. near apex, at least sometimes decumbent (a few stems seen curved at base and rooting there), thickly clad in brown bristles $5-7 \mathrm{~mm}$ long, leafy mainly towards apex, floriferous well down bare stem. Leaves opposite, subisophyllous, largest leaves 220-330 $\times 60-110 \mathrm{~mm}$, including short petiole, elliptic to obovate-elliptic, apex acute, base cuneate, decurrent down short petiole in wings $3-4 \mathrm{~mm}$ broad, wings of leaf pairs briefly united at nodes, margins serrate, each tooth a vein-ending, lateral veins 8-10 each side of midrib, tertiary veins coarsely reticulate becoming scalariform towards margins, upper surface with scattered bristles $2.5-4 \mathrm{~mm}$ long, lower surface (at maturity) glabrous between veins, midrib with brown bristles $5-7 \mathrm{~mm}$ long, lateral veins and veinlets with much shorter, finer, paler hairs. Inflorescence a many-flowered, tightly congested, axillary dichasial cyme; peduncles to $7 \mathrm{~mm}$ long, bristly. Bracts (outermost pair) 20-30 $\times 5-11 \mathrm{~mm}$, elliptic, acute, venation prominent, bracteoles similar but gradually smaller, bristles to $4 \mathrm{~mm}$ long on both surfaces and margins. Pedicels 4-8mm, bristly. Calyx 5-lobed nearly to base, lobes $3-5 \times 0.8-1 \mathrm{~mm}$, narrowly triangular, bristles to c. $4 \mathrm{~mm}$ long on backs and margins. Corolla white with 2 yellow bars on palate darkening to brown in throat, no corollas present on herbarium sheets though mentioned by collectors. Stamens not seen. Disc $1 \times 1 \mathrm{~mm}$, unilateral. Ovary 
$4 \times 1 \mathrm{~mm}$, constricted at base to accommodate disc, glabrous. Style c. $4 \mathrm{~mm}$, very minutely gland-dotted. Stigma bilobed (young). Fruit c. $10 \times 3-3.5 \mathrm{~mm}$, pericarp verrucose. Seeds c. $0.2 \times 0.15 \mathrm{~mm}$, testa dark red-brown.

Other specimens examined. SABAH. Mt. Kinabalu, eastern shoulder, $6^{\circ} 05^{\prime} \mathrm{N}, 116^{\circ} 36-40^{\prime} \mathrm{E}$, Singh's Plateau, 3000ft, 13 vi 1961, Chew et al. 1024 (E, K). Dallas [Dalas, 6²'N, 116²8'E], Bridle trail falls, 3000ft, 17 viii 1931, Clemens 26105 (BM, GH, K).

SARAWAK. Along valley of Ulu Sungai Bejangung, eastern part of Bukit Kana $\left[2^{\circ} 42^{\prime} \mathrm{N}\right.$, 11254'E], 700-850m, 21 xi 1963, Hotta 15418 (E, KYO), but see discussion below.

Cyrtandra latibracteata resembles $C$. phoenicolasia in its conspicuously veined bracts, but lacks petiolar pouches at the nodes, which are a conspicuous feature of that species. It differs further in its larger leaves, bigger bracts, and in the calyx being lobed nearly to the base. Its closest ally is possibly $C$. dorytricha, from which it is distinguished by its much bigger, strongly veined, bracts, longer calyx lobes, and possibly longer fruits. That we have seen no corollas of this species is of little importance; it is features of calyx and gynoecium that are of diagnostic value in this group.

Cyrtandra latibracteata occurs on Mt. Kinabalu, between c.900 and $1000 \mathrm{~m}$ above sea level, in forest. Then there appears to be a record from $3^{\circ}$ further south in Sarawak (Hotta 15418, cited above). This specimen differs from the Kinabalu plant by the presence of long bristles on both the midrib and lateral veins on the lower leaf surface. There is an urgent need for collecting before these forests are completely destroyed by logging.

The leaves of $C$. latibracteata lack sclereids in the spongy mesophyll and a hypodermis may be present or absent; Hotta 15418 has not been checked for sclereids.

5. Cyrtandra dorytricha Hilliard \& B.L.Burtt, sp. nov. a C. megaphylla Hilliard \& B.L.Burtt folio majore paris 150-260 $\times 56-110 \mathrm{~mm}($ nec $270-370 \times 88-150 \mathrm{~mm})$, venis lateralibus paucioribus (5-10 utrinque costae nec 13-20), pedunculis brevioribus (3-7mm nec $15-35 \mathrm{~mm})$ distinguenda.

Type: Borneo, Sarawak, SE end Hose Mts., $2^{\circ} 6^{\prime} \mathrm{N}, 113^{\circ} 42^{\prime} \mathrm{E}$, near Bukit Semako, c. $2200 \mathrm{ft}, 17$ viii 1967, Burtt \& Martin 4948 (holo. E).

Herb, stems to c.600mm tall, c.4-6mm diam. near apex, thickly clad in brown bristles (4-)6-8mm long, leafy mainly towards apex, floriferous to well down the stem. Leaves opposite, isophyllous or almost so, largest major leaves 150-210 $(-260) \times 56-90(-100) \mathrm{mm}$, including petiolar part, obovate to elliptic, apex rather abruptly acute, base cuneate, decurrent down short petiole to form wings c.3 $-5 \mathrm{~mm}$ broad, wings of leaf pairs briefly united at nodes, margins serrate, each tooth a veinending, lateral veins 5-10, tertiary veins coarsely reticulate tending to scalariform towards margins, upper surface clad in scattered bristles, c. $3-7 \mathrm{~mm}$ long on midrib, $2-5 \mathrm{~mm}$ on blade, lower surface glabrous between the veins, all veins and veinlets densely appressed-pubescent, spreading brown bristles as well $3-7 \mathrm{~mm}$ long (longest on midrib). Inflorescence a many-flowered very congested, axillary, dichasial cyme; 
peduncles 3-7mm long, bristly. Bracts (outermost pair) $15-20 \times 1.5-2 \mathrm{~mm}$ at base rapidly and abruptly narrowing to less than $1 \mathrm{~mm}$, venation invisible, bracteoles similar but gradually smaller, bristles $3-5 \mathrm{~mm}$ long. Pedicels $3-4 \mathrm{~mm}$ long, bristly. Calyx 5-lobed nearly to base, lobes c. $2-3 \times 0.5-0.8 \mathrm{~mm}$, narrowly triangular, bristles to $2.5 \mathrm{~mm}$ long outside and on margins, caducous. Corolla white with 2 yellow bars on palate darkening to brown or purplish in throat, c. $12-14 \mathrm{~mm}$ long, tube $9-10 \mathrm{~mm}$ long, cylindric below then abruptly expanded and ventricose on lower side, bilabiate, lower lip 3-5 ×5-8mm, median lobe $2 \times 2-2.5 \mathrm{~mm}$, upper lip $1.5-2 \times 4-5 \mathrm{~mm}$, deeply notched into 2 lobes, outside brown bristles $1-3 \mathrm{~mm}$ long, inside glabrous. Stamens inserted 5-6mm above base of tube, filaments $2-3 \mathrm{~mm}$ long, twisted once, anthers c. $1 \times 0.8 \mathrm{~mm}$, cohering face to face by a very small apiculus; lateral staminodes $0.4-0.8 \mathrm{~mm}$ long, posticous staminode not seen. Disc $1 \times 1 \mathrm{~mm}$, unilateral. Ovary $4 \times 1 \mathrm{~mm}$, glabrous, constricted at base to accommodate disc. Style $3.5-5 \mathrm{~mm}$, very minutely gland-dotted. Stigmatic lobes $0.5 \times 0.3 \mathrm{~mm}$. Fruit $5.5-8 \times 3-4 \mathrm{~mm}$, pericarp verrucose. Seeds c. $0.2 \times 0.15 \mathrm{~mm}$, testa red-brown.

Other specimens examined. SARAWAK. $\left[2^{\circ} 56^{\prime} \mathrm{N}, 112^{\circ} 44^{\prime} \mathrm{E}\right]$, Tatau, path to Bukit Buan, $100 \mathrm{ft}$, 10 vi 1956, Purseglove P5468 (E, K, SING). NE of Bukit Kana $\left[2^{\circ} 42^{\prime} \mathrm{N}, 12^{\circ} 54^{\prime} \mathrm{E}\right], 50-150 \mathrm{~m}$, 22 xi 1963, Hotta 15531 (E, KYO). Bukit Raya [c. $\left.2^{\circ} 10^{\prime} \mathrm{N}, 113^{\circ} \mathrm{E}\right], 31$ iii 1969, Smith S28141 (E). Pelagus Rapids on Sungai Rajang, c. $2^{\circ} 10^{\prime} \mathrm{N}, 113^{\circ} \mathrm{E}, 19$ vii 1962 , Burtt \& Woods B2543 (E). SE end Hose Mts., Bukit Mabong and Ulu Melinau falls area, c. $2^{\circ} 6$ 'N, $113^{\circ} 42^{\prime} \mathrm{E}, 5-20$ viii 1967, Burtt \& Martin B4807 (E).

Cyrtandra dorytricha is allied to $C$. megaphylla from which it is distinguished by its mostly smaller major leaves (c.150-260 ×56-100mm not 270-370 $\times 88-150 \mathrm{~mm}$ ) with fewer lateral veins (5-10 each side of midrib, not 13-20) and shorter peduncles (3-7mm not $15-35 \mathrm{~mm}$ ). Like C. megaphylla, C. dorytricha is confined to Sarawak but their distribution areas, as we know them, scarcely overlap, that of $C$. dorytricha being slightly more northern than that of $C$. megaphylla, but still in the southern half of Sarawak, below the $3^{\circ} \mathrm{N}$ parallel of latitude.

The epithet dorytricha (meaning spear hair) draws attention to the coarse brown bristles that are a characteristic of all the species in this group. Astrosclereids occur in the spongy mesophyll of the leaves; a hypodermis may be present or absent.

Little ecological information is available, but the plants seem to favour streamsides in forest between c.50 and $600 \mathrm{~m}$ above sea level.

6. Cyrtandra brevisetosa Hilliard \& B.L.Burtt, sp. nov. ab C. phoenicolasia Lauterb. saccis transnodalibus absentibus, setis caulinis $1.5-2 \mathrm{~mm}$ longis (nec $3-5 \mathrm{~mm}$ ), calycibus fere ad basin lobatis (nec plus minusve ad medium); ab omnibus speciebus proxime affinibus inter alia setis caulinis $1.5-2 \mathrm{~mm}$ longis (nec 5-12mm) et pilis minutis valde appressis in venis paginae inferioris absentibus differt.

Type: Borneo, Sarawak, Gunong Bunga range from Seropak village, $1^{\circ} 16^{\prime} \mathrm{N}$, $110^{\circ} 09^{\prime}$ E, c. $350 \mathrm{~m}, 6$ iii 1982, Argent \& Sinclair 8230 (holo. E; iso. L, K, KL).

Herb, stem at least 450mm tall, 3-5mm diam., very slender but woody, simple, bark longitudinally finely ridged, leafy only at apex and there clad in brown bristles 
1.5-2mm long, quickly caducous. Leaves opposite, anisophyllous, minor leaf roughly one-third to one-half as long as major leaf, largest major leaves 140$180 \times 50-80 \mathrm{~mm}$, obovate, apex acute, base cuneate, very narrowly decurrent down petiole, margins serrate, lateral veins 14-15 each side of midrib, tertiary veins coarsely reticulate, upper surface clad in scattered brown bristles to $2 \mathrm{~mm}$ long, lower surface glabrous between the veins, midrib and lateral veins in particular with scattered brown bristles 1-3mm long, longest on midrib, otherwise glabrous; petioles $8-15 \mathrm{~mm}$ long. Inflorescence a many-flowered, very congested, dichasial cyme, not plentiful, borne on the bare stem at the nodes well below the leafy stem-apex; peduncles 3-6mm long. Bracts c.15-17 ×4-7mm, elliptic-lanceolate, long-acuminate, triplinerved, upper surface glabrous, lower surface and margins with bristles up to $3 \mathrm{~mm}$ long, bracteoles similar but progressively narrower and slightly shorter $(10-13 \mathrm{~mm})$. Pedicels $2-3 \mathrm{~mm}$ long, bristly. Calyx 5-lobed nearly to base, lobes c. $3 \times 0.5 \mathrm{~mm}$ (in fruit and flower), few bristles c. $2 \mathrm{~mm}$ long near tips of lobes. Corolla white with 2 yellow bars on lower lip darkening to brown in throat, c. $15 \mathrm{~mm}$ long, tube $12 \mathrm{~mm}$, cylindric at base then abruptly expanded and ventricose on lower side, bilabiate, lower lip badly damaged in both flowers seen, upper lip c. $2 \times 4 \mathrm{~mm}$, notched, outside with brown bristles to c. $2 \mathrm{~mm}$ long, inside minutely glandular below sinus on upper lip and on coloured base of lower lip. Stamens inserted c. $7 \mathrm{~mm}$ above base of tube, filaments $5 \mathrm{~mm}$, anthers $1.2 \times 1 \mathrm{~mm}$, cohering face to face by a very small apiculus; lateral staminodes $2 \mathrm{~mm}$, posticous staminode not seen. Disc c. $1 \times 1 \mathrm{~mm}$, unilateral. Ovary $4.5 \times 0.8 \mathrm{~mm}$, constricted at base to accommodate disc, glabrous. Style $4.5 \mathrm{~mm}$, very minutely gland-dotted. Stigmatic lobes c. $1 \times 0.6 \mathrm{~mm}$. Fruit 6-8 $\times 2.5-3 \mathrm{~mm}$, pericarp verrucose. Seeds c. $0.25 \times 0.2 \mathrm{~mm}$, not fully ripe, testa bright red-brown.

Cyrtandra brevisetosa is known to us only from the type collection. The plants were growing in shade among sandstone rocks by a river in the Gunong Bunga Range southwest of Kuching. The species has a distinct facies: long slender stems glabrous except at the apex and leafy there, with few inflorescences scattered down the stem well below the leaves.

The bristles on the stems are distinctly shorter than those of any other species in the group, which character suggested the specific epithet.

7. Cyrtandra hottae B.L.Burtt, Edinburgh J. Bot. 47: 217 (1990).

Type: Borneo, Sarawak, Bintulu distr., eastern part of Bukit Kana $\left[2^{\circ} 42^{\prime} \mathrm{N}\right.$, $112^{\circ} 54^{\prime} \mathrm{E}$ ], along valley of Ulu Sungai Bejangung, 700-850m, 21 xi 1963, Hirano \& Hotta 15377 (holo. KYO, iso. E).

Herb, stem up to c.500mm tall, $4 \mathrm{~mm}$ diam., woody, simple, erect, leafy towards apex, often floriferous well down leafless part, thickly clad in strongly appressed brown bristles. Leaves opposite, strongly anisophyllous, minor leaf c.13-40× 4-12 $\mathrm{mm}$, roughly one-tenth to one-third size of major leaf, largest major leaves $130-190 \times 37-45 \mathrm{~mm}$ including petiolar part, narrowly obovate, abruptly acuminate, base cuneate, decurrent down very short petiolar part, margins crenate-serrate, both 
surfaces clad in red-brown bristles to c.3-5mm long. Inflorescence a 12- to manyflowered, very congested, axillary, dichasial cyme; peduncles c.5-8mm long, bristly. Bracts $12-18 \times 6-9 \mathrm{~mm}$, ovate, bristles to $3 \mathrm{~mm}$ on both surfaces mainly towards margins and on prominent midrib on lower surface; bracteoles similar, scarcely smaller. Pedicels 2-3mm long, setose. Calyx 5-lobed almost to base, lobes c.1.8$2 \times 0.7 \mathrm{~mm}$, narrowly triangular, very few bristles on back of each lobe. Corolla white with a small patch of dark blotches (seen in dried material: no notes on colour by collectors) below the two sinuses of the lower lip, c.13mm long, tube $11 \mathrm{~mm}$, cylindric below then abruptly expanded and ventricose on lower side, bilabiate, lower lip c. $2 \times 6 \mathrm{~mm}$, median lobe $2 \times 2.2 \mathrm{~mm}$, upper lobes $1.5 \times 2.6 \mathrm{~mm}$, outside a few bristly hairs, inside glabrous. Stamens inserted $7 \mathrm{~mm}$ above base of tube, filaments c. $5 \mathrm{~mm}$ long, slightly twisted, anthers $1 \times 0.8 \mathrm{~mm}$, face to face and united at extreme tips, staminodes not seen. Disc c. $1 \times 1 \mathrm{~mm}$, unilateral. Ovary $2.5 \times 1 \mathrm{~mm}$, constricted at base to accommodate style, glabrous. Style c. $2 \mathrm{~mm}$, few minute glandular hairs towards base. Stigmatic lobes c. $0.25 \mathrm{~mm}$ long. Fruit $5 \times 2 \mathrm{~mm}$, pericarp verrucose. Seeds not fully ripe.

Other specimens examined. SARAwaK. Bintulu distr., Mubong to Sungai Latai $\left[2^{\circ} 50^{\prime} \mathrm{N}\right.$, $\left.114^{\circ} 12^{\prime} \mathrm{E}\right]$, along Ulu Sungai Kakus [2 $\left.{ }^{\circ} 48^{\prime} \mathrm{N}, 112^{\circ} 59^{\prime} \mathrm{E}\right], 12$ xi 1963, Hirano \& Hotta 1137 (E, KYO); Ulu Belaga, Sungai Semawat, $3^{\circ} \mathrm{N}, 113^{\circ} 54^{\prime} \mathrm{E}$, Hansen 610 (C).

Cyrtandra hottae is rendered distinctive by the strongly appressed bristles on the stem in contrast to the spreading bristles in the other species of this group. Also, the leaves are often remarkably anisophyllous, and the bracteoles are scarcely smaller than the bracts, giving the inflorescence a very leafy look. Hansen described the stems and undersurface of the leaves as dark purple; the colour is often detectable in dried leaves. The leaves lack sclereids and a hypodermis.

Dr Mitsuru Hotta, Research Associate in the Herbarium, Department of Botany, Kyoto University, collected Bornean plants in the 1960s and donated many duplicates to $\mathrm{E}$.

No further collections have been made since the species was first described in 1990. The plant may have a narrow distribution within Sarawak, between roughly $2^{\circ} 40^{\prime}$ and $3^{\circ} \mathrm{N}, 112^{\circ} 50^{\prime}$ to $113^{\circ} \mathrm{E}$.

\section{ACKNOWLEDGEMENTS}

We are indebted, as ever, to the curators of the following herbaria for sending specimens on loan: The Natural History Museum, London (BM), Botanical Museum, University of Copenhagen (C), Harvard University Herbaria (GH), Royal Botanic Gardens, Kew (K), Botany Department, Kyoto University (KYO), Nationaal Herbarium Nederland, Leiden (L), Botanic Gardens Singapore (SING) and Botany Department, Museum of Natural History, Wroclaw University, Wroclaw (WRSL).

Prof. M.H. Bokhari (Multan, Pakistan) provided the information on leaf anatomy. We sincerely thank Prof. Douglas Henderson for putting our manuscript on disc. 


\section{REFERENCE}

Hilliard, O. M. \& BurtT, B. L. (2004). Bornean species of Cyrtandra

(Gesneriaceae) closely allied to C. chrysea and C. eximia. Kew Bull. 59: 251-259.

Received 31 March 2004; accepted after minor revision 7 December 2004 